\title{
Damage to dopaminergic neurons is mediated by proliferating cell nuclear antigen through the p53 pathway under conditions of oxidative stress in a cell model of Parkinson's disease
}

\author{
DA-WEI LI ${ }^{1,2}$, GUANG-REN LI ${ }^{3}$, BEI-LIN ZHANG ${ }^{2}$, JING-JING FENG ${ }^{2}$ and HUA ZHAO ${ }^{1,2}$ \\ ${ }^{1}$ Neuroscience Research Center, The First Hospital of Jilin University; ${ }^{2}$ Department of Physiology, \\ College of Basic Medical Sciences, Jilin University; ${ }^{3}$ Department of Neurology, \\ The Third Hospital of Jilin University, Changchun, Jilin 130021, P.R. China
}

Received May 5, 2015; Accepted November 30, 2015

DOI: $10.3892 / \mathrm{ijmm} .2015 .2430$

\begin{abstract}
Oxidative stress is widely considered as a central event in the pathogenesis of Parkinson's disease (PD). The mechanisms underlying the oxidative damage-mediated loss of dopaminergic neurons in PD are not yet fully understood. Accumulating evidence has indicated that oxidative DNA damage plays a crucial role in programmed neuronal cell death, and is considered to be at least partly responsible for the degeneration of dopaminergic neurons in PD. This process involves a number of signaling cascades and molecular proteins. Proliferating cell nuclear antigen (PCNA) is a pleiotropic protein affecting a wide range of vital cellular processes, including chromatin remodelling, DNA repair and cell cycle control, by interacting with a number of enzymes and regulatory proteins. In the present study, the exposure of PC12 cells to 1-methyl4-phenylpyridinium $\left(\mathrm{MPP}^{+}\right)$led to the loss of cell viability and decreased the expression levels of PCNA in a dose- and timedependent manner, indicating that this protein may be involved in the neurotoxic actions of $\mathrm{MPP}^{+}$in dopaminergic neuronal cells. In addition, a significant upregulation in p53 expression was also observed in this cellular model of PD. p53 is an upstream inducer of PCNA and it has been recognized as a key contributor responsible for dopaminergic neuronal cell death in mouse models of 1-methyl-4-phenyl-1,2,3,6-tetrahydropyridine (MPTP)-induced PD. This indicates that $\mathrm{MPP}^{+}$-induced oxidative damage is mediated by the downregulation of PCNA
\end{abstract}

Correspondence to: Professor Hua Zhao, Neuroscience Research Center, The First Hospital of Jilin University, 126 Xinmin Street, Changchun, Jilin 130021, P.R. China

E-mail: zhua@jlu.edu.cn

Abbreviations: PD, Parkinson's disease; ROS, reactive oxygen species; $\mathrm{MPP}^{+}$, 1-methyl-4-phenylpyridinium; MPTP, 1-methyl-4phenyl-1,2,3,6-tetrahydropyridine; PCNA, proliferating cell nuclear antigen; DCF, 2'7'-dichlorodihydrofluorescein

Key words: Parkinson's disease, 1-methyl-4-phenylpyridinium, reactive oxygen species, apoptosis, proliferating cell nuclear antigen, p53 through the p53 pathway in a cellular model of PD. Thus, our results may provide some novel insight into the molecular mechanisms responsible for the development of PD and provide new possible therapeutic targets for the treatment of PD.

\section{Introduction}

Parkinson's disease (PD) is a common and chronic neurodegenerative disorder caused by the selective and progressive loss of dopaminergic neurons in the substantia nigra, leading to a depletion of the dopamine neurotransmitter in the striatum (1). While the etiology remains unclear, environmental toxins such as 1-methyl-4-phenyl-1,2,3,6-tetrahydropyridine (MPTP; a lipophilic molecule that rapidly crosses the blood-brain barrier), have been suggested to be involved in the pathogenesis of PD (2-5). Having crossed the barrier, it is oxidized in the brain to its toxic metabolite, 1-methyl-4-phenylpyridinium $\left(\mathrm{MPP}^{+}\right)$, by monoamine oxidase type $\mathrm{B}(\mathrm{MAO}-\mathrm{B})(6)$. $\mathrm{MPP}^{+}$then enters the dopaminergic neurons via the dopamine transporter and is transported to the mitochondria where it causes the inhibition of mitochondrial respiration and energy depletion, by interacting with the respiration complex I (7), leading to reactive oxygen species (ROS) production (8-11). ROS production is widely recognized as a major initiator triggering sequential events leading to the degeneration of dopaminergic neurons (12-15). Postmortem studies of the brains of patients with PD have shown increased levels of 4-hydroxy-2-nonenal (HNE), a by-product of lipid peroxidation $(16,17)$ and carbonyl modifications of soluble proteins (18), supporting the involvement of oxidative damage in dopaminergic neuron degeneration. The well-known parkinsonism inducers, MPTP, rotenone and 6-hydroxydopamine (6-OHDA) have been shown to cause ROS production and the degeneration of dopaminergic neurons in animal models, further supporting the involvement of oxidative stress in the pathogenesis of PD (19-23). The molecular mechanisms responsible for the gradual loss of dopaminergic neurons under conditions of oxidative stress are not yet fully understood.

However, DNA damage-mediated cell death has been suggested to be associated with neuronal cell death in PD (24). This is supported by analyses showing selective increases in levels of DNA and RNA oxidation products, 8-hydroxy- 
deoxyguanosine and 8-hydroxy-guanosine, in the substantia nigra during postmortem studies of brains affected by PD $(25,26)$. Oxidative DNA damage has also been observed in the brains tissue of mice exposed to MPTP and other neuronal toxins that induce a PD-like pathology (27). Proliferating cell nuclear antigen (PCNA) is a well known determinant of DNA biological function, including DNA replication and repair, as well as cell cycle control $(28,29)$, and thus plays a crucial role in maintaining in the integrity of the genome, as well as cell survival. Previous studies have shown that PCNA plays a role in the repair of DNA damage under conditions of oxidative stress $(30,31)$. In this study, we examined the changes in the levels of this protein in $\mathrm{MPP}^{+}$-stimulated $\mathrm{PC} 12$ cells, in order to identify potential causes of dopaminergic neuron degeneration and to elucidate the underlying molecular mechanisms. Our results demonstrated that $\mathrm{MPP}^{+}$induced the loss of cell viability and the apoptosis of dopaminergic neuronal cells, in a time- and dose-dependent manner. $\mathrm{MPP}^{+}$also decreased PCNA protein expression, and this was accompanied by the impairment of PC12 cells, suggesting a correlation between the levels of this protein and damage to PC12 cells under conditions of oxidative stress. Notably, $\mathrm{MPP}^{+}$induced the significant upregulation of p53 expression, which is an upstream modulator of PCNA and has been recognized as a key contributor responsible for dopaminergic neuronal cell death in mouse models of MPTPinduced PD $(32,33)$. Overall, these findings indicate that PCNA may play a crucial role in oxidative stress-induced damage to dopaminergic neurons, thus, providing a therapeutic target for molecular-based strategies in the treatment of PD.

\section{Materials and methods}

Drugs and chemicals. All reagents and chemicals were purchased from Sigma-Aldrich (St. Louis, MO, USA) unless stated otherwise.

Cell culture. The rat adrenal pheochromocytoma cell line, PC12, was purchased from the Cell Bank of the Chinese Academy of Sciences (Shanghai, China). The cells were maintained in high glucose Dulbecco's modified Eagle's medium (DMEM) supplemented with $100 \mathrm{U} / \mathrm{ml}$ of penicillin, $100 \mu \mathrm{g} / \mathrm{ml}$ of streptomycin, $4 \mathrm{mM}$ L-glutamine and 10\% inactivated fetal serum, (Gibco, Grand Island, NY, USA). The cultures were maintained in a $5 \% \mathrm{CO}_{2}$ incubator at $37^{\circ} \mathrm{C}$.

Cell viability assay. The viability of the $\mathrm{PC} 12$ cells was evaluated using the modified 3-(4,5-dimethylthiazol-2-yl)-2,5-diphenyltetrazolium bromide (MTT) assay.MTT is reduced by metabolically active cells to form blue formazan crystals. The PC12 cells were plated on 96-well plates at a density of 30,000 cells $/ \mathrm{cm}^{2}$ and incubated for $24 \mathrm{~h}$. To assess the toxicity of $\mathrm{MPP}^{+}$to the $\mathrm{PC} 12$ cells, the cells were exposed to various concentrations of $\operatorname{MPP}^{+}(0.5,1$ and $2 \mathrm{mM}$ ). MTT solution $(5 \mathrm{mg} / \mathrm{ml})$ was then added to each well and the cells were incubated for $4 \mathrm{~h}$. The culture medium was removed, and the formazan crystals were dissolved in dimethyl sulfoxide (DMSO). The absorbance of the colored solution was measured at $570 \mathrm{~nm}$ using a microplate reader (Epoch; BioTek, Winooski, VT, USA). The results are expressed as a percentage of the absorbance of the control culture wells (cells not exposed to $\mathrm{MPP}^{+}$). The experiment was repeated 3 times.
Nuclear staining assay. Morphological changes in the cell nuclei induced by $\mathrm{MPP}^{+}$were evaluated using acridine orange/ethidium bromide $(\mathrm{AO} / \mathrm{EB})$ staining. The PC12 cells were plated on 6-well plates at a density of 30,000 cells $/ \mathrm{cm}^{2}$ and incubated in DMEM for $24 \mathrm{~h}$. Following exposure to $1 \mathrm{mM} \mathrm{MPP}^{+}$for $48 \mathrm{~h}$, the cells were washed and resuspended in phosphate-buffered saline (PBS) followed by the addition of AO/EB (final concentration $1 \mu \mathrm{g} / \mathrm{ml})$. The cells were then examined under a fluorescence microscope (IX71; Olympus Corp., Tokyo, Japan). Living cells with intact structures were stained green, whereas early apoptotic cells exhibited condensed green nuclei, and late apoptotic cells exhibited condensed red-orange chromatin. At least 300 cells were randomly observed and the number of apoptotic cells is expressed as a percentage of the total number of cells counted.

DNA fragmentation assay. DNA denaturation in the apoptotic cells was determined by a single-stranded DNA (ssDNA) assay using an ssDNA apoptosis enzyme-linked immunosorbent assay (ELISA) kit (Chemicon International, Temecula, CA, USA), according to the manufacturer's instructions. This procedure is based on the ability of a monoclonal antibody to detect ssDNA in apoptotic cells but not in necrotic cells. The cells at a concentration of 30,000 cells $/ \mathrm{cm}^{2}$ were cultured for $24 \mathrm{~h}$, followed by treatment with various concentrations $(0.5,1$, $2 \mathrm{mM}$ ) of $\mathrm{MPP}^{+}$. Following $24 \mathrm{~h}$ of incubation, the staining of ssDNA was performed, and ssDNA fragmentation was determined by measuring the absorbance at a wavelength of $405 \mathrm{~nm}$ using a microplate reader (Epoch; BioTek).

Measurement of oxidative stress. Oxidative stress was measured in the PC12 cells using 2'-7'-dichlorofluorescein diacetate (DCFHDA) based on the ROS-dependent oxidation of DCFH-DA to fluorescent dichlorofluorescein (DCF). DCFH-DA easily crosses the membrane into cells and is converted into non-fluorescent dichlorofluorescein (DCFH) by intracellular esterase. DCFH is then oxidized into highly fluorescent DCF by intracellular ROS, thereby the density of fluorescence reflects an overall index of oxidative activity. Following exposure, the cells were incubated in bovine serum albumin (BSA)-free DMEM with DCFH-DA at a final concentration of $20 \mu \mathrm{M}$ for $30 \mathrm{~min}$ at $37^{\circ} \mathrm{C}$. Thereafter, the cells in each group were analyzed by flow cytometry using the FL1 flow cytometer detection channels (BD Biosciences, San Jose, CA, USA). The excitation wavelength was $485 \mathrm{~nm}$ and the reading was performed at $530 \mathrm{~nm}$.

Western blot analysis. Following exposure to $\mathrm{MPP}^{+}$, the PC12 cells were harvested and lysed with cell lysis solution containing 4\% sodium dodecyl sulfate (SDS), 2 mM EDTA, $50 \mathrm{mM}$ Tris- $\mathrm{HCl}$ (pH 6.8). Equal amounts of protein were loaded onto a $12 \%$ SDS-polyacrylamide gel. Following electrophoretic separation, the gels were transferred onto PVDF membranes (Amersham Biosciences, Uppsala, Sweden). The membranes were subsequently incubated in Tris-buffered saline/Tween-20 (TBST) buffer supplemented with $5 \%$ fat-free milk for $1 \mathrm{~h}$. The membranes were then blotted with mouse monoclonal anti-rat PCNA antibodies (Cat. no. 610664; BD Biosciences) and mouse monoclonal anti-rat p53 antibodies (Cat. no. 554157; BD Biosciences), and horseradish peroxidase-conjugated anti-mouse secondary antibodies (Cat. no. R-21455; Pierce Biotechnology, Inc., 


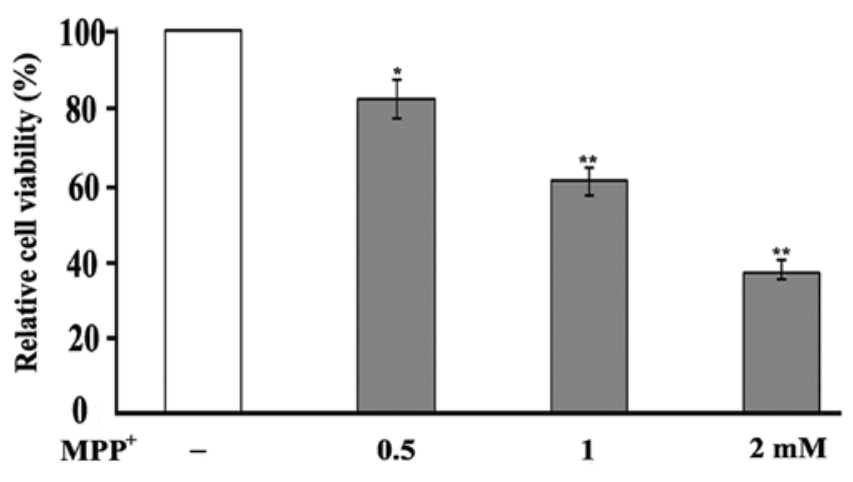

Figure 1. 1-Methyl-4-phenylpyridinium $\left(\mathrm{MPP}^{+}\right)$reduces the viability of $\mathrm{PC12}$ cells. PC12 cells were exposed to the indicated concentrations of MPP for $48 \mathrm{~h}$ Cell viability was determined by an MTT assay as described in the Materials and methods. Data are presented as the means \pm SEM of 3 independent experiments performed in sixplicate. ${ }^{*} \mathrm{P}<0.05$ or ${ }^{* *} \mathrm{P}<0.01$ vs. control (no exposure).

Rockford, IL, USA) were used as the secondary antidodies. $\beta$-actin was used as an internal control.

Statistic analysis. Data are expressed as the means \pm SEM. Statistical analysis was performed using one-way analysis of variance (ANOVA) or a Student's t-test. A value of $\mathrm{P}<0.05$ was considered to indicate a statistically significant difference.

\section{Results}

$M P P^{+}$induces the loss of the viability of PC12 cells. The oxidative damage induced by $\mathrm{MPP}^{+}$to the $\mathrm{PC} 12$ cells was examined by MTT assay, a colorimetric assay used for measuring the activity of mitochondrial dehydrogenases in metabolically active cells. The measurements revealed a decrease in cell viability following the exposure of $\mathrm{PC} 12$ cells to $\mathrm{MPP}^{+}$in a dose-dependent manner. Following $48 \mathrm{~h}$ of exposure to $0.5 \mathrm{mM}$ $\mathrm{MPP}^{+}$, cell viability was reduced to $82 \%$ of the control, while exposure to 1 and $2 \mathrm{mM} \mathrm{MPP}^{+}$decreased cell viability to 61 and $37 \%$ of the control, respectively (Fig. 1).

$\mathrm{MPP}^{+}$induces the apoptosis of dopaminergic neurons. To examine the $\mathrm{MPP}^{+}$-induced apoptosis of the $\mathrm{PC} 12$ cells, an AO/EB staining assay and a DNA fragmentation assay were performed. Apoptosis is a process of programmed cell death characterized by a series of distinct nuclear morphological changes, which can be detected by AO/EB staining. Exposure to $\mathrm{MPP}^{+}$significantly increased the percentage of apoptotic cells in a concentration-dependent manner (Fig. 2). To further examine the toxic effects of $\mathrm{MPP}^{+}$on the PC12 cells, DNA fragmentation was investigated by an ssDNA assay. The results revealed an increase in DNA fragmentation following exposure to $\mathrm{MPP}^{+}$(Fig. 3), thus incating that $\mathrm{MPP}^{+}$is toxic to $\mathrm{PC} 12$ cells .

$M P P^{+}$induces the production of ROS. To determine whether $\mathrm{MPP}^{+}$-induced damage is mediated by oxidative damage in $\mathrm{PC} 12$ cells, the level of ROS production was evaluated by flow cytometry with DCFH-DA. DCFH-DA is a stable compound that easily diffuses into cells where it is converted into DCFH by intracellular esterase. DCFH is then trapped within cells and oxidized to highly fluorescent DCF by intracellular ROS; thereby, the intensity of the fluorescence produced by DCF may reflect an intracellular oxidative state. Exposure to $\mathrm{MPP}^{+}$induced a significant increase in DCFH oxidation in the PC12 cells (Fig. 4), which supports the hypothesis that oxidative damage is involved in the degeneration of dopaminergic neurons.

$M P P^{+}$decreases PCNA expression in dopaminergic neuronal cells. To determine whether PCNA is involved in dopaminergic neuronal cell death under conditions of oxidative stress, the
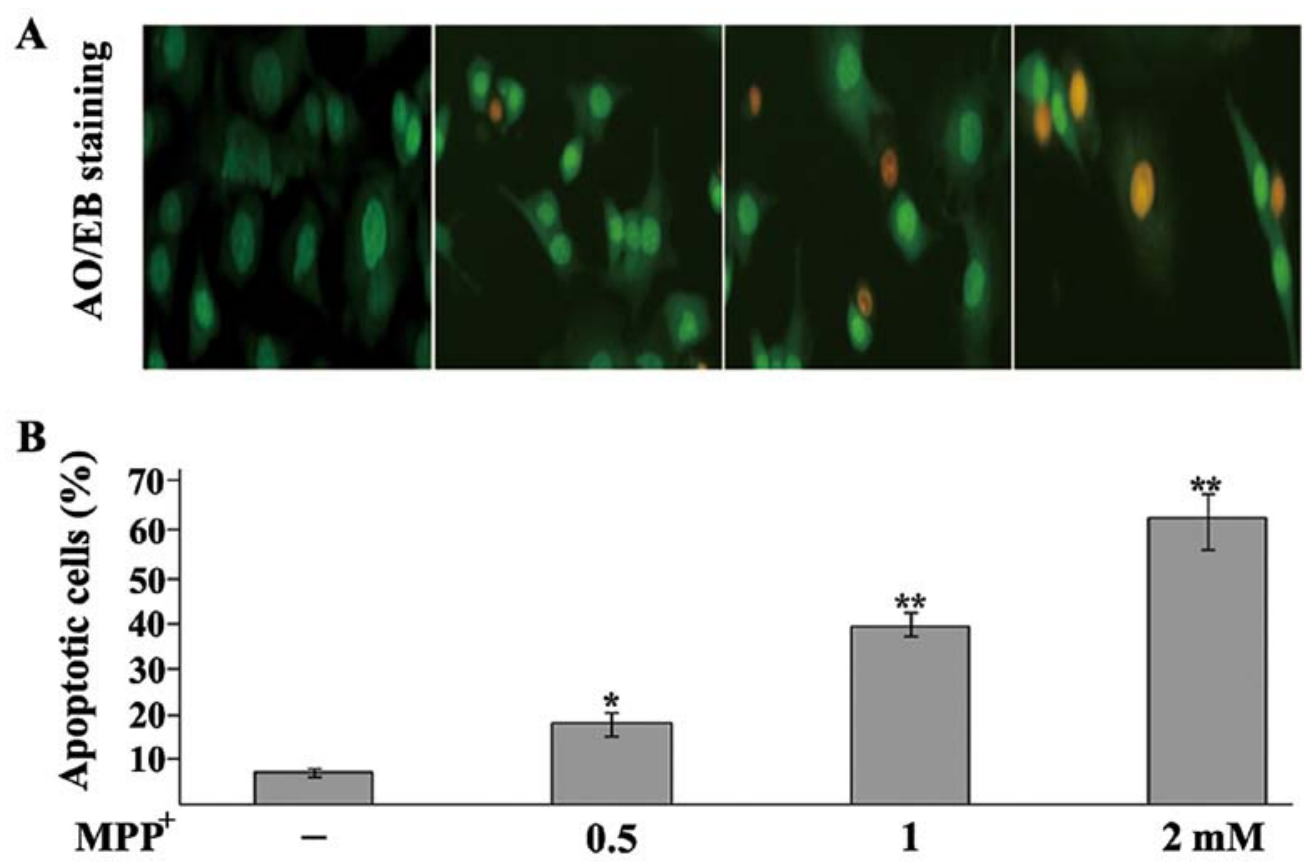

Figure 2. Effect of 1-methyl-4-phenylpyridinium $\left(\mathrm{MPP}^{+}\right)$on neuronal cell apoptosis. (A) PC12 cells were exposed to the indicated concentrations of MPP ${ }^{+}$for $48 \mathrm{~h}$, then apoptosis was analyzed using the acridine orange/ethidium bromide staining (AO/EB) assay. (B) The histograms show the percentage of apoptotic cells. Data are presented as the means \pm SEM. $n=3$ experiments. ${ }^{*} \mathrm{P}<0.05$ or ${ }^{* *} \mathrm{P}<0.01$ vs. control (no exposure). 


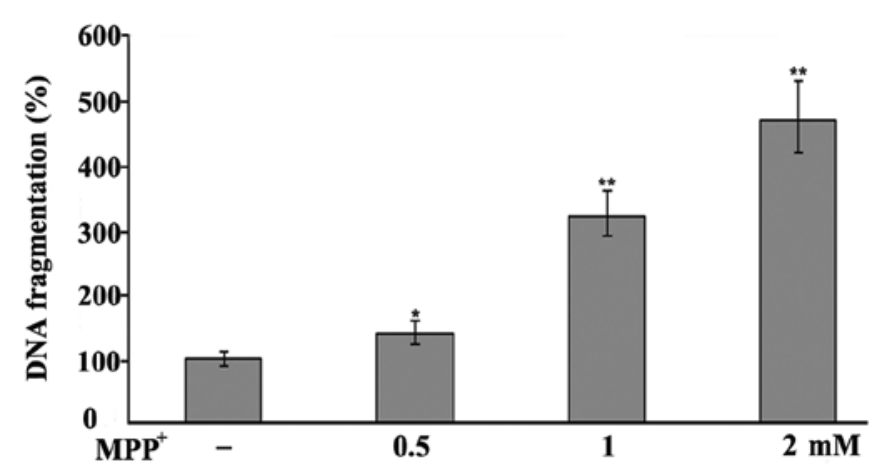

Figure 3. Determination of the effects of $\mathrm{MPP}^{+}$on the apoptosis of $\mathrm{PC} 12$ cells using a single-stranded DNA assay. The histograms show the percentage of cells with DNA fragmentation. Data are presented as the means \pm SEM. $n=3$ experiments. ${ }^{*} \mathrm{P}<0.05$ or ${ }^{* *} \mathrm{P}<0.01$ vs. control (no exposure).

expression levels of PCNA were measured in a cellular model of $\mathrm{MPP}^{+}$-induced PD. Firstly, we examined whether $\mathrm{MPP}^{+}$ induced toxicity to the $\mathrm{PC} 12$ cells in a time-dependent manner. The PC12 cells were exposed to $1 \mathrm{mM} \mathrm{MPP}^{+}$, and then cell viability was determined after 12,24 and $48 \mathrm{~h}$ by an MTT assay. The results revealed that exposure of the PC12 cells to
$1 \mathrm{mM} \mathrm{MPP}^{+}$for $12 \mathrm{~h}$ caused cell viability to decrease to $87 \%$ of the control, whereas exposure for 24 and $48 \mathrm{~h}$ decreased cell viability to 77 and $61 \%$ of the control, respectively (Fig. 5A). In addition, exposure to $1 \mathrm{mM} \mathrm{MPP}{ }^{+}$reduced PCNA protein expression in the PC12 cells. Consistent with the changes observed in cell viability, PCNA expression was decreased from $12 \mathrm{~h}$ and further decreased until $48 \mathrm{~h}$ following exposure to $1 \mathrm{mM} \mathrm{MPP}^{+}$in the PC12 cells (Fig. 5B), thus indicating that PCNA is involved in the $\mathrm{MPP}^{+}$-induced degeneration of dopaminergic neurons.

$M P P^{+}$increases the epression of p53 in dopaminergic neurons. In order to elucidate the mechanisms through which $\mathrm{MPP}^{+}$ decreases PCNA expression in $\mathrm{MPP}^{+}$-exposed PC12 cells, we examined a well-known PCNA upstream regulator, p53. p53 has been suggested to play a pivotal role in dopaminergic neuronal cell death in a mouse model of MPTP-induced PD $(33,34)$, and transcriptional activation is the principal mechanism through which PCNA expression is regulated. Our results revealed that $\mathrm{p} 53$ expression was upregulated following exposure to $0.5 \mathrm{mM} \mathrm{MPP}{ }^{+}$and further upregulated following exposure to 1 and $2 \mathrm{mM} \mathrm{MPP}$ in the PC12 cells (Fig. 6A). In contrast to 553 expression, PCNA expression was decreased in a dose-dependent manner following exposure to the indicated

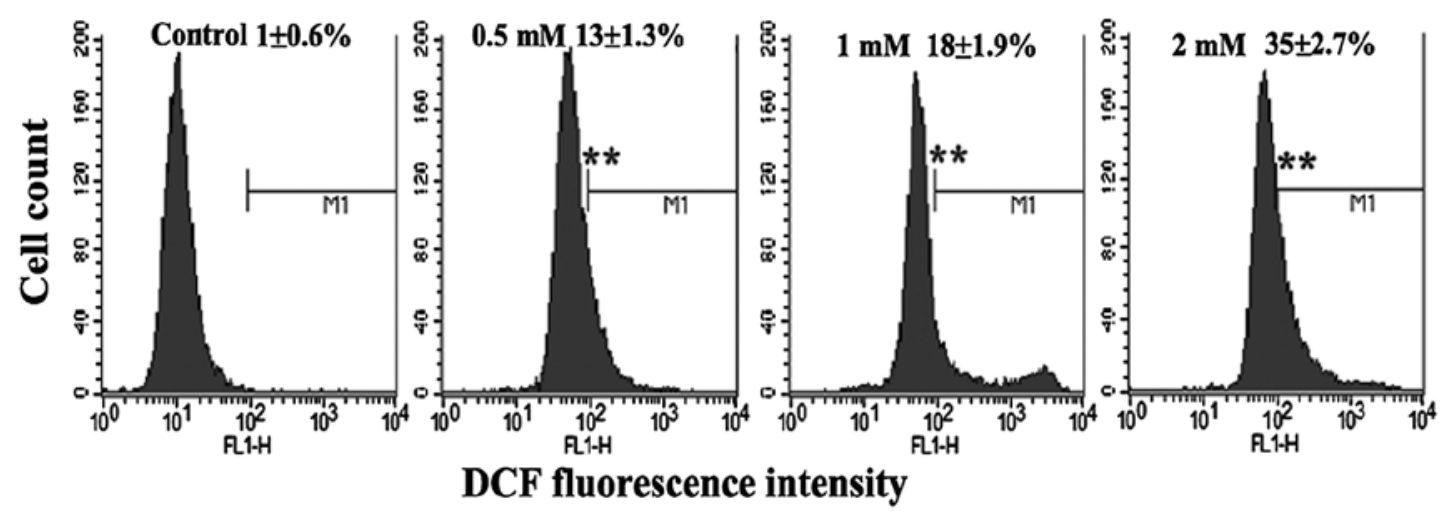

Figure 4. Effects of 1-methyl-4-phenylpyridinium $\left(\mathrm{MPP}^{+}\right)$on reactive oxygen species (ROS) production. PC12 cells were exposed to the indicated concentrations of $\mathrm{MPP}^{+}$for $48 \mathrm{~h}$. The production of ROS in the cells was measured by flow cytometry with DCFH-DA. The graphs display the relative levels of ROS production compared with the control (cells not exposed to MPP'). Data are presented as the means \pm SEM. $n=3$ experiments. ${ }^{* *}<<0.01$ vs. control.

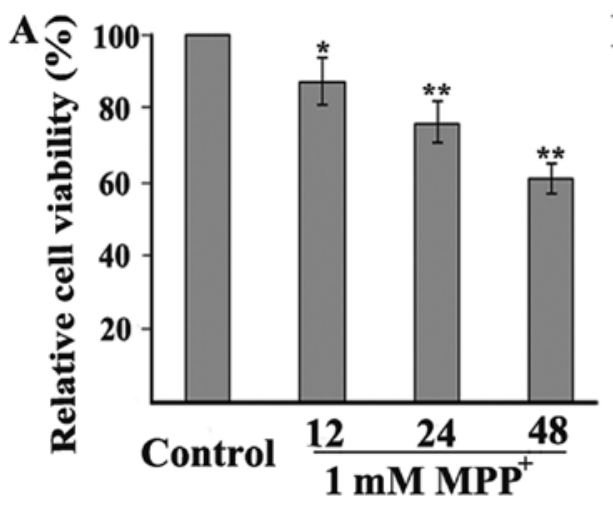

B

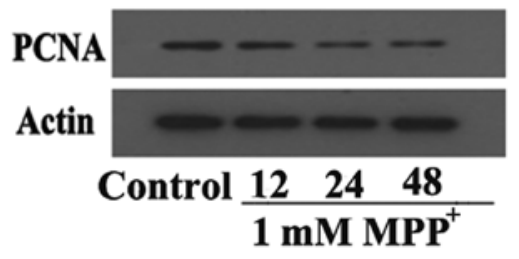

Figure 5. 1-Methyl-4-phenylpyridinium $\left(\mathrm{MPP}^{+}\right)$reduces cell viability and proliferating cell nuclear antigen (PCNA) expression. (A) PC12 cells were exposed to $1 \mathrm{mM} \mathrm{MPP}^{+}$, then the cell viability was determined after 12, 24 and $48 \mathrm{~h}$ using an MTT assay. Data are presented as the means \pm SEM of 3 independent experiments performed in sixplicate. Error bars represent the means $\pm \mathrm{SEM}\left({ }^{*} \mathrm{P}<0.05\right.$ and $\left.{ }^{* *} \mathrm{P}<0.01\right)$. (B) PCNA protein expression in $\mathrm{PC} 12$ cells exposed to $1 \mathrm{mM} \mathrm{MPP}{ }^{+}$ for the indicated periods of time was determined by western blot analysis. Actin expression was used as a loading control. 
A
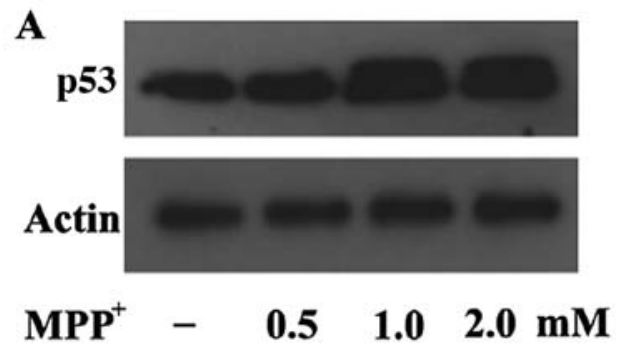

B

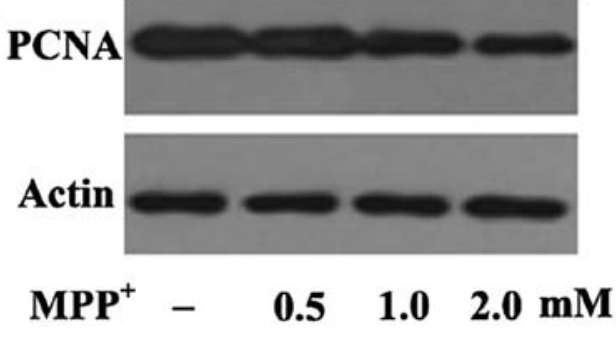

Figure 6. Expression levels of proliferating cell nuclear antigen (PCNA) and p53 in 1-methyl-4-phenylpyridinium (MPP ${ }^{+}$-exposed PC12 cells. PC12 cells were exposed to $1 \mathrm{mM} \mathrm{MPP}^{+}$for $48 \mathrm{~h}$. The expression levels of (A) p53 and (B) PCNA were determined by western blot analysis, and actin expression was used as a loading control.

concentrations of $\mathrm{MPP}^{+}$(Fig. 6B), suggesting a negative correlation between $\mathrm{p} 53$ and PCNA expression under conditions of oxidative stress.This further indicates that $\mathrm{MPP}^{+}$-induced oxidative damage is mediated by the downregulation of PCNA through the p53 pathway in a cellular model of PD.

\section{Discussion}

In this study, we demonsrated that the pleiotropic protein PCNA is involved in the damage to dopaminergic neurons in neurodegenerative conditions, and that the downregulated expression of this protein may be mediated by the p53 signaling pathway. PCNA is an essential protein involved in DNA replication and repair (35), and the dysregulation of its expression may aggravate oxidative stress-induced DNA damage, a central event involved in the neuronal cell death in PD (25). The downregulation of PCNA is at least partly responsible for the DNA damage-mediated death of dopaminergic neurons, thus providing a potential target for the molecular-based therapeutic management of PD.

$\mathrm{PD}$ is a common neurodegenerative movement disorder, clinically characterized by rigidity, resting tremor, bradykinesia and postural instability, caused by the degeneration and death of dopaminergic neurons in the pars compacta of the substantia nigra (36). Although the cellular and molecular mechanisms underlying the loss of dopaminergic neurons in PD remain unclear, accumulating evidence indicates that increased levels of oxidative stress play a crucial role in triggering a programmed cell death cascade, involved in the pathogenesis of PD $(24,37)$. Oxidative damage is a pathological event responsible for a number of human diseases, including cardiovascular, metabolic, inflammatory and neurodegenerative diseases, as well as cancer (25,27,38-41). Dopaminergic neurons are more prone to oxidative damage due to high levels of lipids, iron as well as dopamine metabolism (42-51). Oxidative stress is mainly elicited by the excessive production of ROS, including hydrogen peroxide $\left(\mathrm{H}_{2} \mathrm{O}_{2}\right)$, superoxide anion and hydroxyl radical (52-54). The overproduction of ROS damages nucleic acids, including DNA and RNA, finally causing cell death. This pathological mechanism is thought to be at least partly responsible for the death of dopaminergic neurons in PD. Postmortem studies on PD-affected brains and on brain tissue from mice exposed to MPTP and other neuronal toxins that induce a PD-like pathology have shown increased oxidative DNA damage, selectively targeting dopaminergic neurons of substantia nigra pars compacta $(25,27)$, strongly implicating
DNA damage-induced cell death as a causative factor of PD. DNA is the most important determinant of cell survival and death. Replication and repair are required for DNA integrity, since DNA is frequently subjected to damage by endogenous and environmental toxic agents (55). Under pathological conditions, numerous mechanisms are involved in DNA repair to protect against DNA damage $(56,57)$. PCNA is an essential protein in DNA replication, and its function was originally described as the auxiliary protein of DNA polymerases (35). However, PCNA has also been shown to affect multiple vital cellular processes, including chromatin remodeling, DNA repair and cell cycle control $(35,58)$. PCNA has no intrinsic enzymatic activity, and its complex role in cells depends on its capacity to regulate other proteins. PCNA interacts with a wide range of enzymes and regulatory proteins, such as cyclin-dependent kinases (CDKs) (59) or the CDK inhibitor p21/waf1 (60), which allows this protein to modulate a wide range of biological functions. In differentiated neutrophils, for example, it was found that cytoplasmic PCNA sequesters procaspases and prevents their activation, promoting the cell survival (61). Additionally, PCNA plays a crucial role in the repair of DNA damage under conditions of oxidative stress $(30,31)$. In this study, we found that the neurotoxin, $\mathrm{MPP}^{+}$, a well-established inducer of parkinsonism-like symptoms in humans and primates, induced an increase in ROS productino and in the number of apoptotic dopaminergic neurons, supporting the involvement of oxidative stress in the pathogenesis of PD. Importantly, exposure to $\mathrm{MPP}^{+}$ also decreased the expression level of PCNA in a time- and dose-dependent manner, suggesting the involvement of PCNA in $\mathrm{MPP}^{+}$-induced neuronal toxicity in PD. The downregulation of this protein may aggravate DNA damage under pathological conditions due to the crucial role of PCNA in maintaining DNA integrity against various insults including oxidative damage. However, the mechanisms responsible for this change in PCNA expression in a cellular model of $\mathrm{MPP}^{+}$-induced PD remain unclear.

The transcription factor p53 modulates a set of target genes that are involved in a wide range of cellular processes, including cell cycle progression, DNA repair, apoptosis and cellular stress responses (62-65). p53-dependent apoptosis in neuronal cells is mainly mediated by DNA damage $(66,67)$. The overproduction of ROS activates p53, leading to further DNA damage under conditions of oxidative stress. It is well known that p53 is an upstream inducer of PCNA. The interaction of p53 with the PCNA promoter, the specific sequence for the p53 binding site, regulates the production of this protein. Higher concentra- 
tions of wild-type p53 inhibit the PCNA promoter and reduce PCNA expression $(68,69)$. Evidence has indicated that p53 is upregulated and plays a pivotal role in dopaminergic neuronal cell death in mouse models of MPTP-induced PD $(33,34)$. It has been demonstrated that p53 inhibitors are highly effective in reducing damage to dopaminergic neurons and in preserving motor function in a mouse model of PD (33). Consistent with these reports, our results demonstrated that $\mathrm{MPP}^{+}$significantly increased p53 expression in dopaminergic neuronal cells, supporting the involvement of p53 in the pathogenesis of PD. In addition, a decrease in PCNA expression was also observed in the cells exposed to $\mathrm{MPP}^{+}$, and this expression pattern is in contrast to that of 553 expression, suggesting a negative correlation between $\mathrm{p} 53$ and PCNA expression under conditions of oxidative stress. Taken together, these findings suggest that a PCNA-dependent apoptotic pathway is a potential molecular mechanism that is involved in neuronal cell death in PD, and the p53 signaling pathway is also implicated in this process.

In the present study, we present evidence that $\mathrm{MPP}^{+}$-induced oxidative damage is mediated by the downregulation of PCNA through the $\mathrm{p} 53$ pathway in a cellular model of $\mathrm{PD}$. The cellular and molecular mechanisms responsible for the effects of PCNA on dopaminergic neurons require further elucidation, and may provide a potential and efficient therapeutic target for molecular-based strategies for the treatment of PD.

\section{References}

1. Forno LS: Neuropathology of Parkinson's disease. J Neuropathol Exp Neurol 55: 259-272, 1996.

2. Langston JW and Irwin I: MPTP: Current concepts and controversies. Clin Neuropharmacol 9: 485-507, 1986.

3. Kopin IJ and Markey SP: MPTP toxicity: implications for research in Parkinson's disease. Annu Rev Neurosci 11: 81-96, 1988.

4. Heikkila RE, Sieber BA, Manzino L and Sonsalla PK: Some features of the nigrostriatal dopaminergic neurotoxin 1-methyl4-phenyl-1,2,3,6-tetrahydropyridine (MPTP) in the mouse. Mol Chem Neuropathol 10: 171-183, 1989.

5. Calon F, Lavertu N, Lemieux AM, Morissette M, Goulet M, Grondin R, Blanchet PJ, Bédard PJ and Di Paolo T: Effect of MPTP-induced denervation on basal ganglia GABA(B) receptors: correlation with dopamine concentrations and dopamine transporter. Synapse 40: 225-234, 2001.

6. Chiba K, Trevor A and Castagnoli N Jr: Metabolism of the neurotoxic tertiary amine, MPTP, by brain monoamine oxidase. Biochem Biophys Res Commun 120: 574-578, 1984.

7. Javitch JA, D'Amato RJ, Strittmatter SM and Snyder SH: Parkinsonism-inducing neurotoxin, N-methyl-4-phenyl1,2,3,6-tetrahydropyridine: uptake of the metabolite N-methyl4-phenylpyridine by dopamine neurons explains selective toxicity. Proc Natl Acad Sci USA 82: 2173-2177, 1985.

8. Akaneya Y, Takahashi M and Hatanaka H: Involvement of free radicals in $\mathrm{MPP}^{+}$neurotoxicity against rat dopaminergic neurons in culture. Neurosci Lett 193: 53-56, 1995.

9. Jenner P: Oxidative mechanisms in nigral cell death in Parkinson's disease. Mov Disord 13 (Suppl 1): 24-34, 1998.

10. Przedborski S and Vila M: The 1-methyl-4-phenyl-1,2,3,6-tetrahydropyridine mouse model: a tool to explore the pathogenesis of Parkinson's disease. Ann N Y Acad Sci 991: 189-198, 2003.

11. Segura Aguilar J and Kostrzewa RM: Neurotoxins and neurotoxic species implicated in neurodegeneration. Neurotox Res 6: 615-630, 2004.

12. Schapira AH and Jenner P: Etiology and pathogenesis of Parkinson's disease. Mov Disord 26: 1049-1055, 2011.

13. Zhu J and Chu CT: Mitochondrial dysfunction in Parkinson's disease. J Alzheimers Dis 20 (Suppl 2): S325-S334, 2010.

14. Parker WD Jr, Parks JK and Swerdlow RH: Complex I deficiency in Parkinson's disease frontal cortex. Brain Res 1189: 215-218, 2008.
15. Jenner $\mathrm{P}$ and Olanow $\mathrm{CW}$ : The pathogenesis of cell death in Parkinson's disease. Neurology 66 (Suppl 4): S24-S36, 2006.

16. Jenner P: Oxidative stress in Parkinson's disease. Ann Neurol 53 (Suppl 3): S26-S38, 2003.

17. Yoritaka A, Hattori N, Uchida K, Tanaka M, Stadtman ER and Mizuno Y: Immunohistochemical detection of 4-hydroxynonenal protein adducts in Parkinson disease. Proc Natl Acad Sci USA 93: 2696-2701, 1996.

18. Floor E and Wetzel MG: Increased protein oxidation in human substantia nigra pars compacta in comparison with basal ganglia and prefrontal cortex measured with an improved dinitrophenylhydrazine assay. J Neurochem 70: 268-275, 1998.

19. Callio J, Oury TD and Chu CT: Manganese superoxide dismutase protects against 6-hydroxydopamine injury in mouse brains. J Biol Chem 280: 18536-18542, 2005.

20. Vila $\mathrm{M}$ and Przedborski S: Targeting programmed cell death in neurodegenerative diseases. Nat Rev Neurosci 4: 365-375, 2003.

21. Perier C, Bové J, Vila M and Przedborski S: The rotenone model of Parkinson's disease. Trends Neurosci 26: 345-346, 2003

22. Sun SY, An CN and Pu XP: DJ-1 protein protects dopaminergic neurons against 6-OHDA/MG-132-induced neurotoxicity in rats. Brain Res Bull 88: 609-616, 2012.

23. Heikkila RE, Hess A and Duvoisin RC: Dopaminergic neurotoxicity of 1-methyl-4-phenyl-1,2,5,6-tetrahydropyridine in mice. Science 224: 1451-1453, 1984.

24. Mattson MP: Apoptosis in neurodegenerative disorders. Nat Rev Mol Cell Biol 1: 120-129, 2000.

25. Alam ZI, Jenner A, Daniel SE, Lees AJ, Cairns N, Marsden CD, Jenner $\mathrm{P}$ and Halliwell B: Oxidative DNA damage in the parkinsonian brain: an apparent selective increase in 8-hydroxyguanine levels in substantia nigra. J Neurochem 69: 1196-1203, 1997.

26. Zhang J, Perry G, Smith MA, Robertson D, Olson SJ, Graham DG and Montine TJ: Parkinson's disease is associated with oxidative damage to cytoplasmic DNA and RNA in substantia nigra neurons. Am J Pathol 154: 1423-1429, 1999.

27. Mandir AS, Przedborski S, Jackson-Lewis V, Wang ZQ, Simbulan-Rosenthal CM, Smulson ME, Hoffman BE, Guastella DB, Dawson VL and Dawson TM: Poly(ADP-ribose) polymerase activation mediates 1-methyl-4-phenyl-1, 2,3,6-tetrahydropyridine (MPTP)-induced parkinsonism. Proc Natl Acad Sci USA 96: 5774-5779, 1999.

28. Tan CK, Castillo C, So AG and Downey KM: An auxiliary protein for DNA polymerase-delta from fetal calf thymus. J Biol Chem 261: 12310-12316, 1986.

29. Prelich G, Tan CK, Kostura M, Mathews MB, So AG, Downey KM and Stillman B: Functional identity of proliferating cell nuclear antigen and a DNA polymerase-delta auxiliary protein. Nature 326: 517-520, 1987.

30. Burkovics P, Hajdú I, Szukacsov V, Unk I and Haracska L: Role of PCNA-dependent stimulation of 3'-phosphodiesterase and 3'-5' exonuclease activities of human Ape2 in repair of oxidative DNA damage. Nucleic Acids Res 37: 4247-4255, 2009.

31. Amoroso A, Concia L, Maggio C, Raynaud C, Bergounioux C, Crespan E, Cella R and Maga G: Oxidative DNA damage bypass in Arabidopsis thaliana requires DNA polymerase $\lambda$ and proliferating cell nuclear antigen 2. Plant Cell 23: 806-822, 2011.

32. Hirata $\mathrm{H}$ and Cadet JL: p53-knockout mice are protected against the long-term effects of methamphetamine on dopaminergic terminals and cell bodies. J Neurochem 69: 780-790, 1997.

33. Duan W, Zhu X, Ladenheim B, Yu QS, Guo Z, Oyler J, Cutler RG, Cadet JL, Greig NH and Mattson MP: p53 inhibitors preserve dopamine neurons and motor function in experimental parkinsonism. Ann Neurol 52: 597-606, 2002.

34. Trimmer PA, Smith TS, Jung AB and Bennett JP Jr: Dopamine neurons from transgenic mice with a knockout of the p53 gene resist MPTP neurotoxicity. Neurodegeneration 5: 233-239, 1996.

35. Moldovan GL, Pfander B and Jentsch S: PCNA, the maestro of the replication fork. Cell 129: 665-679, 2007.

36. Samii A, Nutt JG and Ransom BR: Parkinson's disease. Lancet 363: 1783-1793, 2004.

37. Li DW, Yao M, Dong YH, Tang MN, Chen W, Li GR and Sun BQ: Guanosine exerts neuroprotective effects by reversing mitochondrial dysfunction in a cellular model of Parkinson's disease. Int J Mol Med 34: 1358-1364, 2014.

38. Trachootham D, Alexandre J and Huang P: Targeting cancer cells by ROS-mediated mechanisms: a radical therapeutic approach? Nat Rev Drug Discov 8: 579-591, 2009.

39. Martinon F: Signaling by ROS drives inflammasome activation. Eur J Immunol 40: 616-619, 2010. 
40. Bhat AH, Dar KB, Anees S, Zargar MA, Masood A, Sofi MA and Ganie SA: Oxidative stress, mitochondrial dysfunction and neurodegenerative diseases; a mechanistic insight. Biomed Pharmacother 74: 101-110, 2015.

41. He F and Zuo L: Redox roles of reactive oxygen species in cardiovascular diseases. Int J Mol Sci 16: 27770-27780, 2015.

42. Lotharius J and Brundin P: Pathogenesis of Parkinson's disease: dopamine, vesicles and alpha-synuclein. Nat Rev Neurosci 3 : 932-942, 2002

43. Montine KS, Quinn JF, Zhang J, Fessel JP, Roberts LJ II, Morrow JD and Montine TJ: Isoprostanes and related products of lipid peroxidation in neurodegenerative diseases. Chem Phys Lipids 128: 117-124, 2004.

44. Nagatsu T and Sawada M: Molecular mechanism of the relation of monoamine oxidase B and its inhibitors to Parkinson's disease: possible implications of glial cells. J Neural Transm Suppl 71: 53-65, 2006

45. Kumar MJ and Andersen JK: Perspectives on MAO-B in aging and neurological disease: where do we go from here? Mol Neurobiol 30: 77-89, 2004.

46. Norris EH, Giasson BI, Hodara R, Xu S, Trojanowski JQ, Ischiropoulos H and Lee VM: Reversible inhibition of alpha-synuclein fibrillization by dopaminochrome-mediated conformational alterations. J Biol Chem 280: 21212-21219, 2005.

47. Zecca L, Wilms H, Geick S, Claasen JH, Brandenburg LO Holzknecht C, Panizza ML, Zucca FA, Deuschl G, Sievers J and Lucius R: Human neuromelanin induces neuroinflammation and neurodegeneration in the rat substantia nigra: implications for Parkinson's disease. Acta Neuropathol 116: 47-55, 2008

48. Sadrzadeh SM and Saffari Y: Iron and brain disorders. Am J Clin Pathol 121 (Suppl): S64-S70, 2004.

49. Jomova $\mathrm{K}$ and Valko M: Advances in metal-induced oxidative stress and human disease. Toxicology 283: 65-87, 2011.

50. Núñez MT, Urrutia P, Mena N, Aguirre P, Tapia V and Salazar J: Iron toxicity in neurodegeneration. Biometals 25: 761-776, 2012.

51. Lan J and Jiang DH: Desferrioxamine and vitamin E protect against iron and MPTP-induced neurodegeneration in mice. J Neural Transm 104: 469-481, 1997.

52. Fang J, Seki $\mathrm{T}$ and Maeda $\mathrm{H}$ : Therapeutic strategies by modulating oxygen stress in cancer and inflammation. Adv Drug Deliv Rev 61: 290-302, 2009.

53. Fruehauf JP and Meyskens FL Jr: Reactive oxygen species: a breath of life or death? Clin Cancer Res 13: 789-794, 2007.

54. Day BJ: Catalytic antioxidants: A radical approach to new therapeutics. Drug Discov Today 9: 557-566, 2004.

55. Nikitaki Z, Hellweg CE, Georgakilas AG and Ravanat JL: Stress-induced DNA damage biomarkers: applications and limitations. Front Chem 3: 35, 2015.
56. Aziz K, Nowsheen S, Pantelias G, Iliakis G, Gorgoulis VG and Georgakilas AG: Targeting DNA damage and repair: embracing the pharmacological era for successful cancer therapy. Pharmacol Ther 133: 334-350, 2012.

57. Smolarz B, Wilczyński J and Nowakowska D: DNA repair mechanisms and human cytomegalovirus (HCMV) infection. Folia Microbiol (Praha) 60: 199-209, 2015.

58. Mailand N, Gibbs-Seymour I and Bekker-Jensen S: Regulation of PCNA-protein interactions for genome stability. Nat Rev Mol Cell Biol 14: 269-282, 2013.

59. Koundrioukoff S, Jónsson ZO, Hasan S, de Jong RN, van der Vliet PC, Hottiger MO and Hübscher U: A direct interaction between proliferating cell nuclear antigen (PCNA) and Cdk2 targets PCNA-interacting proteins for phosphorylation. J Biol Chem 275: 22882-22887, 2000.

60. Waga S, Hannon GJ, Beach D and Stillman B: The p21 inhibitor of cyclin-dependent kinases controls DNA replication by interaction with PCNA. Nature 369: 574-578, 1994.

61. Witko-Sarsat V, Mocek J, Bouayad D, Tamassia N, Ribeil JA, Candalh C, Davezac N, Reuter N, Mouthon L, Hermine O, et al: Proliferating cell nuclear antigen acts as a cytoplasmic platform controlling human neutrophil survival. J Exp Med 207: 2631-2645, 2010.

62. Polyak K, Xia Y, Zweier JL, Kinzler KW and Vogelstein B: A model for p53-induced apoptosis. Nature 389: 300-305, 1997.

63. Mirza A, Wu Q, Wang L, McClanahan T, Bishop WR, Gheyas F, Ding W, Hutchins B, Hockenberry T, Kirschmeier P, et al: Global transcriptional program of $\mathrm{p} 53$ target genes during the process of apoptosis and cell cycle progression. Oncogene 22: 3645-3654, 2003.

64. Vogelstein B, Lane D and Levine AJ: Surfing the p53 network. Nature 408: 307-310, 2000.

65. Zhao R, Gish K, Murphy M, Yin Y, Notterman D, Hoffman WH, Tom E, Mack DH and Levine AJ: Analysis of p53-regulated gene expression patterns using oligonucleotide arrays. Genes Dev 14: 981-993, 2000

66. Chipuk JE and Green DR: Dissecting p53-dependent apoptosis. Cell Death Differ 13: 994-1002, 2006.

67. Culmsee $C$ and Mattson MP: p53 in neuronal apoptosis. Biochem Biophys Res Commun 331: 761-777, 2005.

68. Morris GF, Bischoff JR and Mathews MB: Transcriptional activation of the human proliferating-cell nuclear antigen promoter by p53. Proc Natl Acad Sci USA 93: 895-899, 1996.

69. Shivakumar CV, Brown DR, Deb S and Deb SP: Wild-type human p53 transactivates the human proliferating cell nuclear antigen promoter. Mol Cell Biol 15: 6785-6793, 1995. 